\title{
EDITORIAL
}

\section{La integración de la institución universitaria al mundo público en época de pandemia}

\author{
The integration of the university institution to the public \\ world in times of the pandemic
}

\author{
Rodrigo Ferrer Urbina \\ Dirección de Investigación, \\ Postgrado y Transferencia \\ Tecnológica \\ Universidad de Tarapaca \\ Arica, Chile \\ rferrer@academicos.uta.cl
}

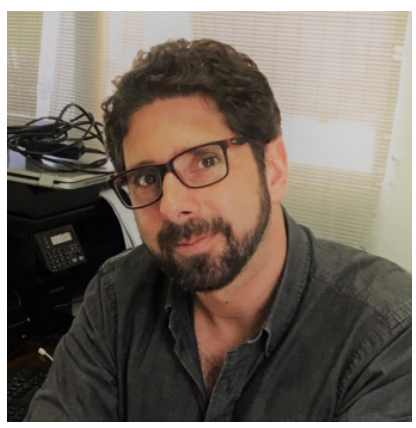

Rodrigo Ferrer Urbina Directorate of Research, Postgraduate Studies and Technology Transfer Universidad of Tarapaca Arica, Chile rferrer@academicos.uta.cl
El 2020 ha sido un año que ha puesto todo, y a todos, de cabeza, con duros efectos económicos, políticos, psicológicos, sociales y, principalmente, implicando un gran dolor para millones de personas que han tenido que despedirse, abruptamente y a la distancia, de sus seres queridos. Las universidades, centros de investigación, y el mundo de la ciencia en general, no han estado exentos de este dramático escenario, con la dificultad adicional que involucra asumir la responsabilidad de intensificar esfuerzos para intentar ser un faro que alumbre la esperanza de un futuro pospandémico.

Si bien la pandemia ha focalizado la atención de la opinión pública, y los financiamientos, en el desarrollo de una posible vacuna y en los modelos epidemiológicos, el aporte que las universidades hacen para superar el coronavirus se extiende desde apoyos profesionales y técnicos a los sistemas de salud, hasta propuestas de soluciones a los problemas que nos quedarán cuando pase, incluyendo los que ya arrastrábamos desde hace décadas.

La Facultad de Ciencias Agronómicas de la Universidad de Tarapacá no ha estado al margen de esta responsabilidad y desafío, reacondicionando sus equipos, adaptando sus procedimientos y reinventando a sus investigadores para transitar desde la detección genética aplicada a las ciencias agronómicas hacia la detección de SARS CoV-2, mediante PCR en tiempo real. El reto es
2020 has been a year that has turned every thing, and everyone, upside down, with harsh economic, political, psychological, social effects and, above all, involving great pain for millions of people who have had to say goodbye, abruptly and from a distance, to their loved ones. Universities, research centers, and the world of science, in general, have not been exempt from this dramatic scenario, with the additional difficulty involved in assuming the responsibility of intensifying efforts to try to be a beacon that lights up the hope of a post-pandemic future.

The pandemic has been the focused of public opinion. In contrast, funding, has focused on the development of a possible vaccine and epidemiological models. The universities' contribution to overcome the coronavirus extends from professional and technical support to the health systems to proposals of solutions to problems that will remain when it passes, including those we have already dragged for decades.

The Faculty of Agricultural Sciences of the Universidad de Tarapacá has not been exempted from this responsibility and challenge, reconditioning its equipment, adapting its procedures, and reinventing its researchers to move from genetic detection applied to agronomic sciences to the detection of SARS CoV-2 through realtime PCR. The challenge is to become a direct 
transformarse en un aporte directo a la pesquisa de casos activos de COVID-19 y la contención de la pandemia, mediante la detección temprana y el rastreo de contactos directos.

Esta iniciativa se materializó a través de un convenio entre la Seremía de Ciencias de la Macrozona Norte, la Seremía de Salud de Arica y Parinacota y la Facultad de Ciencias Agronómicas de la Universidad de Tarapacá, que finalmente se tradujo en la creación del Laboratorio de Salud Pública, Ambiental y Laboral (LABSAL), dependiente de la Seremía de Salud, pero operada directamente por personal investigador y técnico de nuestra universidad. Ello da cuenta del potencial que tienen las universidades regionales de volcar sus experticias internas en pos de dar respuesta a las necesidades nacionales y regionales.

Sin duda, al igual que hemos hecho a lo largo de la historia de la humanidad, nuestra especie sobrevivirá a esta dolorosa experiencia, pero no sin haberse transformado enormemente. Esperamos que estas transformaciones también den paso al cambio de las universidades y del quehacer científico en general, a fin de que crezcan en integración con el mundo público y privado, con una participación más activa en la solución de los problemas centrales de la comunidad global y construyendo puentes para acercar la ciencia y el conocimiento a las personas, ayudando a proteger a la población de los nefastos efectos de la desinformación, las "fake news" y las teorías pseudocientíficas. contributor to the investigation of active cases of COVID-19 and the containment of the pandemic through early detection and direct contact tracking.

This initiative was materialized through an agreement between the Northern Macrozone Science Seremi, the Arica and Parinacota Health Seremia, and the Faculty of Agronomic Sciences of the Universidad de Tarapacá, which finally resulted in the creation of the Laboratory of Public, Environmental and Work Health (LABSAL), under the Health Seremia, but managed directly by research and technical staff of our university. This initiative shows the regional universities' potential to use their internal expertise to counter national and regional needs.

Undoubtedly, as we have done throughout humanity's history, our species will survive this painful experience, but not without having been significantly transformed. Our Hope is that these transformations will also give way to universities' changes and the scientific endeavor in general. Thus, growing further integration with the public and private world, with more active participation in the solution of the global community's central problems and building bridges to bring science and knowledge closer to people, helping to protect the people from the harmful effects of disinformation, "fake news" and pseudo-scientific theories. 